\title{
Conference
}

\section{Training Hero for Hero: Training for Increasing The Psychological Well-Being of Citizens Abroad}

\author{
Nur Eva ${ }^{1 *}$, Pravissi Shanti ${ }^{1}$, Aji Bagus Priyambodo ${ }^{1}$, Tutut Chusniyah ${ }^{2}$, Sri \\ Andayani ${ }^{1,2}$, Najway Azka Ar-Robbaniy ${ }^{1,2}$, Syafira Triesna Adinda ${ }^{1}$, Bakhitah \\ Jihan Wijaya ${ }^{1}$, Witrie Annisa ${ }^{3}$ \\ ${ }^{1}$ Psychological Education Faculty, State University of Malang, Malang, Indonesia \\ ${ }^{2}$ Faculty of Psychology, Airlangga University, Surabaya, Indonesia \\ ${ }^{3}$ Islamic Education, Universiti Brunei Darussalam, Bandar Sri Begawan, Brunei \\ ORCID \\ Nur Eva: https://orcid.org/0000-0003-3584-5049
}

Corresponding Author: Nur Eva; email: nur.eva.fppsi@um.ac.id

Dates

Published 28 January 2022

Publishing services provided by Knowledge E

(c) Nur Eva et al. This article is distributed under the terms of the Creative Commons

Attribution License, which permits unrestricted use and redistribution provided that the original author and source are credited.

Selection and Peer-review under the responsibility of the ICoPsy Conference Committee.

\section{G OPEN ACCESS}

\begin{abstract}
This research is an initial study aimed at digging up information on how effective the training called Hero to Hero Training is in improving the psychological well-being of Indonesian citizens abroad. Psychological well-being variable was measured using Ryff's Psychological Well-Being scale which has been adapted into Indonesian. The research design used was a quasi-experimental pre-post test design. The treatment provided is online training. There are 33 subjects in this study and the status is not only PMI in the domestic sector. The data were analyzed using Wilcoxon and resulted in a $p$ value of $0.002<0.05$ so that there was a significant difference in the level of psychological well-being of the participants after attending the training.
\end{abstract}

Keywords: Indonesian Workers, Indonesian Migrant Workers Abroad

\section{Introduction}

Indonesian citizens abroad are not only Indonesian Workers (TKI), now they have changed their names to Indonesian Migrant Workers (PMI). Many of them are Indonesian citizens with other interests such as continuing their study to the colleges or doing business. Discriminatory phenomena related to work as migrant workers are still often encountered, especially in female workers. The simplest example is the behavior of labeling or stigmatizing female workers as slaves or maids which generally has a negative connotation. Indicators of economic ability, level of education, and the limited special skills possessed are common reasons for former female workers to receive discriminatory treatment.

Data sourced from the Department of Manpower and Transmigration states that among $92 \%$ of the total number of foreign workers, the majority are Indonesian migrant workers who work in the informal sector. Most of the jobs in the informal sector are in the fields of household assistants, child caretakers, taking care of the elderly in housing, 
whose standardization of expertise is determined by the factory. The prevalence of problems experienced by Indonesian Workers (TKI) during the migration process has also been recorded to increase. Throughout 2017, there were at least 369 cases handled by BP3TKI Mataram. There are various types, ranging from non-procedural departures, unilateral layoffs at work, insurance claims, salaries that are not in accordance with the contract, and various acts of violence received by migrant workers [1].

In addition to external things, the difficulties experienced by former Indonesian Workers (TKI)/Indonesian Female Workers (TKW) come from themselves. After moving to a new environment where many things are new for them, i.e. new friends, so that a new habit that was not done previously then was performed when an individual becomes a TKI/TKW. This is what triggers the emergence of various changes experienced by TKI/TKW abroad. No less complex problems must also be faced by TKI/TKW who experience unpleasant treatment while they still have a migrant status or other problems they face related to their return to the country. The form of unpleasant treatment received is often verbal abuse, such as being ridiculed or being the object of gossip from the surrounding community. The tendency to continue to pay attention to the opinion of the community, often changes the perspective of the TKI/TKW themselves in interpreting their lives as a whole. These problems affect their psychological well-being. According to Deci \& Ryan [2] Psychological well-being is usually conceptualized as a state of life that is going well, indicated by a combination of pleasant feelings that arise such as happiness and the ability to develop optimal self-function both for oneself and for others. In the end, the problems experienced by TKI/TKW create limitations for themselves in expressing themselves in the midst of community life. Limited hope, optimism, resilience, and self-efficacy, will make them feel psychologically unwell.

Improving the welfare of TKI and TKW is not only done by giving material appreciation. Psychological well-being also needs to be improved. So far, the training conducted for TKI/TKW is related to their work skills and competencies. Training to improve psychological well-being also needs to be given to TKI/TKW. The psychological aspects given in the training cannot be just one aspect, but the collaboration of several related aspects. Psychological well-being needs to be improved for TKI/TKW, one of which is through training.

According to [3] explains that the first simple thing you can do to distract yourself from feeling sad and depressed is to build hopeful thoughts. Diversion of other negative feelings can also be done by doing various positive activities. In addition to hope, a feeling of optimism is also built that can lead individuals to view life positively. Optimistic individuals will be able to interpret life now as something that can support 
the achievement of their life goals. There are many benefits of optimistic thinking including being able to view challenges as positive, reducing stress, and other variables that support psychological well-being. Carver, et al explained that there is a positive relationship between optimism and psychological well-being [4]. Optimistic individuals are more able to control their negative feelings so that psychological well-being is achieved.

\section{Literature Review}

Ryff \& Keyes said that psychological well-being (PWB) is the full achievement of one's psychological potential and a state in which the individual is able to accept his or her strengths and weaknesses [5]. PWB is related to social interactions, personal relationships, and life satisfaction [6]. PWB is also related to harmony, kindness, and establishing relationships with other people, both individuals and groups [7]. Happiness is the result of psychological well-being, where happiness is the highest goal that humans want to achieve [8].

Psychological well-being has six dimensions, namely, self-acceptance, positive relations, autonomy, environmental mastery, purpose in life, personal growth, and affection. Self-acceptance is the main characteristic of psychological well-being. Individuals accept themselves as they are and be positive about themselves. Positive relations is a dimension that emphasizes the importance of establishing warm and trusting relationships with others. Autonomy emphasizes a person's ability to determine himself and regulate his own behavior, able to resist social pressures, and evaluate himself with personal standards. Environmental mastery is the ability to manipulate situations so that they are in accordance with the needs and values they hold and are able to develop themselves creatively. Purpose in life is the ability to achieve life goals and interpret all of his life journeys. Personal growth is the ability to develop one's potential continuously and grow. Affection is the ability to be accepted by others so that it receives a lot of love from the surrounding environment. Factors that influence psychological well-being are age, gender, level of education and occupation, cultural background, physical attractiveness, level of autonomy and religiosity, opportunity to interact with others, and being able to balance expectations and achievements. 
TABLE 1: Training Hero for Hero Activities

\begin{tabular}{|c|c|c|}
\hline Session & Activity & Purpose \\
\hline 1 & $\begin{array}{l}\text { Introduction and delivery of psycho- } \\
\text { logical problems experienced }\end{array}$ & $\begin{array}{l}\text { The purpose of this session was gets to } \\
\text { know about each participants. In addition, } \\
\text { to dig deeper into the participants' psycho- } \\
\text { logical problems }\end{array}$ \\
\hline 2 & $\begin{array}{l}\text { Material } 1 \text { Knowing Psychological } \\
\text { Well-Being }\end{array}$ & $\begin{array}{l}\text { This session was conducted to provide } \\
\text { participants with brief knowledge about } \\
\text { psychological well-being and its benefits }\end{array}$ \\
\hline 3 & $\begin{array}{l}\text { Material } 2 \text { Anchor and The Visual } \\
\text { Squash }\end{array}$ & $\begin{array}{l}\text { This session was conducted to provide } \\
\text { knowledge about the Anchor and The } \\
\text { Visual Squash techniques in dealing with } \\
\text { psychological problems }\end{array}$ \\
\hline 4 & Role Play 1 & $\begin{array}{l}\text { This section aims to practice the Anchor } \\
\text { and The Visual Squash techniques by the } \\
\text { trainees }\end{array}$ \\
\hline 5 & Material 3 Relaxation & $\begin{array}{l}\text { This session is conducted to provide } \\
\text { knowledge about Relaxation techniques in } \\
\text { dealing with psychological problems }\end{array}$ \\
\hline 6 & Role Play 2 & $\begin{array}{l}\text { This section aims to practice Relaxation } \\
\text { techniques by trainees }\end{array}$ \\
\hline 7 & Review & $\begin{array}{l}\text { This session aims to explore what the } \\
\text { participants feel through discussion. }\end{array}$ \\
\hline
\end{tabular}

\section{Method}

This study uses an experimental research design of one group pre-post test design. The treatment given is in the form of training to improve psychological well-being with the title Hero for Hero Training which is carried out online. The subjects who participated in this training were 33 people.

The following is the research procedure carried out:

1. Participants were asked to fill in the psychological well-being scale to measure the level of psychological well-being before the training

2. Participants take part in a series of Hero for Hero Training activities

3. Participants were asked to fill in the psychological well-being scale to measure the level of psychological well-being after the training

\section{Result}

The training was attended by participants who are Indonesian citizens living abroad for work. Table 1 shows that more than 50 percent have a graduate degree. 
TABLE 2: Data Demography

\begin{tabular}{|c|c|c|}
\hline Education & Number & $\%$ \\
\hline School/Vocational & 8 & 24 \\
\hline Undergraduate (S1)/Equal & 25 & 76 \\
\hline \multicolumn{3}{|l|}{ Job } \\
\hline Teacher & 11 & 33 \\
\hline Private & 7 & 21 \\
\hline Freelance & 15 & 46 \\
\hline
\end{tabular}

TABLE 3: Descriptive Statistics

\begin{tabular}{l|l|l|l|l} 
Data & N & Mean & SD & SE \\
Pre-Test & 33 & 75.788 & 9.562 & 1.664 \\
Post-Test & 35 & 80.879 & 16.405 & 2.856
\end{tabular}

The data analyzed showed that the mean value of the post test was higher than that of the pre-test. The difference between the two is 5.091. This means that there is an increase in the psychological well-being of the participants after the training.

Before testing the hypothesis, the data normality test will be carried out using the Shapiro-Wilk method. This method was used because the amount of data analyzed was less than 30 . The results of the data normality test showed that the data were not normally distributed with $p=0.001<0.05$.

Hypothesis testing in this study resulted in a $p$ value $=0.002<0.05$, meaning that there was a difference between before and after the training. The magnitude of the effect of treatment in the form of training on the post test results is indicated by the matched rank biserial correlation value below 1 , which is -0.627 , which means that the treatment effect is of small value.

\section{Discussion}

Demographically, this training was attended by 33 participants and resulted in an increase in the level of psychological well-being. This training is included in small group training. Research shows that small group training positively affects participant participation and improves learning outcomes [9]. This could happen because group

TABLE 4: Normality Test

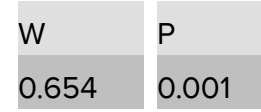


TABLE 5: Hypothesis Testing

\begin{tabular}{lllll|l|l|} 
Test & Statistic & df & $P$ & $\begin{array}{l}\text { Location } \\
\text { Parameter }\end{array}$ & $\begin{array}{l}\text { SE } \\
\text { Difference }\end{array}$ & Effect Size \\
Student & -1.394 & 32 & 0.173 & -5.091 & 3.653 & -0.243 \\
Wilcoxon & 104.5 & & 0.002 & -7.00 & & -0.627
\end{tabular}

size affects the social dynamics within the group, larger groups are associated with decreased individual student performance, poorer social interactions and less diversity [10]. Smaller groups have greater social cohesion and greater perception of task [11]. Therefore, the size of the training participants can be one of the causes of the success of this training.

The education level of the trainees is mostly undergraduate, according to research, the level of education affects the results of online training [12]. Higher education background will motivate an individual to learn and get to know what he learns in training [13]. The explanation above can be interpreted that higher education is able to influence a person's drive to try to understand what is conveyed in the training so that this can be used as a reference for why this training can be successful. With the same level of education, these participants can be said to be a peer group. A study found that peer group intervention contributed $51.9 \%$ in improving psychological well-being [14].

The training in this research was conducted online. A study shows that online learning does not provide full benefits and the online learning process is neglected by participants [15]. Another study compared mental health interventions with online and in-person media or offline, the results showed that online interventions could be an alternative but the results could not be compared to those carried out offline. [15]. This could be one of the possible small effects of treatment on participants even though there are still changes in the level of psychological well-being.

Work is one of the factors that influence the psychological well-being of individuals. In this study, most of the trainees worked in the education sector, so they were familiar with learning methods using online media, especially during the pandemic. So this is one of the factors that also affects the increasing level of psychological well-being of the trainees.

\section{Conclusion}

In conclusion, Hero for Hero training can increase the psychological capital of individuals with the status of Indonesian citizens domiciled abroad. The success of this training is 
supported by the homogeneous characteristics of the trainees in terms of education and work.

\section{Acknowledgment}

This research was funded by the State University of Malang's Non-Tax Revenue Grant (PNBP) of 2021.

\section{References}

[1] Rakasi, D., Hakim, L., \& Hartono, R. (2019). GAMBARAN KESEJAHTERAAN PSIKOLOGIS MANTAN TENAGA KERJA WANITA. JURNAL PSIMAWA, 1(1), 1-6. https://doi.org/10.1234/jp.v1i1.202

[2] Deci, E. L., \& Ryan, R. M. (1985). Intrinsic motivation and self-determination in human behavior. New York: Springer Science \& Business Media.

[3] Hutchinson, E. (2011). The psychological well-being of orphans in Malawi: "Forgetting" as a means of recovering from parental death. Vulnerable Children and Youth Studies, 6(1), 18-27. https://doi.org/10.1080/17450128.2010.525672

[4] Carver, C. S., Pozo, C., Harris, S. D., Noriega, V., Scheier, M. F., Robinson, D. S., Ketcham, A. S., Moffat, F. L., \& Clark, K. C. (1993). How coping mediates the effect of optimism on distress: A study of women with early stage breast cancer. Journal of Personality and Social Psychology, 65(2), 375-390. https://doi.org/10.1037//00223514.65.2.375

[5] Ryff, C. D., \& Keyes, C. L. M. (1995). The structure of psychological wellbeing revisited. Journal of Personality and Social Psychology, 69(4), 719-727. https://doi.org/10.1037/0022-3514.69.4.719

[6] Hoyer, W. J., \& Roodin, P. (2009). Adult development and aging (6th ed). New York: McGraw-Hill.

[7] Ramos, R.L. (2007). In the eye of the beholder: Implicit theories of happiness among Filipino adolescents. Philippine Journal of Counseling Psychology, 9 (1), 96- 127

[8] Bradburn, N. M., Noll, C. E., \& Center, N. O. R. (1969). The Structure of Psychological Well-being. London: Aldine Publishing Company.

[9] Shaw, R.-S. (2013). The relationships among group size, participation, and performance of programming language learning supported with online forums. Computers \& Education, 62, 196-207. https://doi.org/10.1016/j.compedu.2012.11.001 
[10] Saqr, M., Nouri, J., \& Jormanainen, I. (2019). A Learning Analytics Study of the Effect of Group Size on Social Dynamics and Performance in Online Collaborative Learning. In M. Scheffel, J. Broisin, V. Pammer-Schindler, A. Ioannou, \& J. Schneider (Eds.), Transforming Learning with Meaningful Technologies (pp. 466-479). New York: Springer International Publishing. https://doi.org/10.1007/978-3-030-29736-7_35

[11] Carron, A. V., \& Spink, K. S. (1995). The Group Size-Cohesion Relationship in Minimal Groups. Small Group Research, 26(1), 86-105. https://doi.org/10.1177/1046496495261005

[12] Yu, Z. (2021). The effects of gender, educational level, and personality on online learning outcomes during the COVID-19 pandemic. International Journal of Educational Technology in Higher Education, 18(1), 14. https://doi.org/10.1186/s41239021-00252-3

[13] Irdianto, W., \& Putra, A. B. N. R. (2016). The influence of education and economic background towards the training participants' motivation and study result of UPT-PK Singosari Malang. 030061. https://doi.org/10.1063/1.4965795

[14] Linayaningsih, F., I.w, M. V., \& Savitri, A. D. (2017). Pengaruh Pelatihan Peer Group Counseling dalam meningkatkan Psychological Well-Being pada Siswa Sekolah Menengah Pertama. PHILANTHROPY: Journal of Psychology, 1(1), 25-35. https://doi.org/10.26623/philanthropy.v1i1.774

[15] Ma, H., Yao, J., \& Liu, L. (2017). Research on the Correlation between Learning Effectiveness and Online Learning Behavior Based on Online Education Scene. Creative Education, 8(13), 2187-2198. https://doi.org/10.4236/ce.2017.813149 